\title{
Correction to: Vermicomposting Smart Closed Reactor Design and Performance Assessment by Using Sewage Sludge
}

\author{
Mona Ghorbani $^{1,2} \cdot$ Mohammad Reza Sabour $^{1} \cdot$ Masoud Bidabadi $^{3}$
}

Published online: 17 December 2021

(c) Springer Nature B.V. 2021

\section{Correction to: \\ Waste and Biomass Valorization (2021) 12:6177-6190 \\ https://doi.org/10.1007/s12649-021-01426-w}

Following publication of the original article, the author identified an error in the affiliation.
Publisher's Note Springer Nature remains neutral with regard to jurisdictional claims in published maps and institutional affiliations.

The original article can be found online at https://doi.org/10.1007/ s12649-021-01426-w.

Mona Ghorbani

mona.ghorbani@queensu.ca

1 Faculty of Civil Engineering, K.N. Toosi University of Technology, No. 1346, Vali Asr, Street, Mirdamad Intersection, Tehran, Iran

2 Faculty of Civil Engineering, Queen's University, 99 University Ave, Kingston, ON K7L 3N6, Canada

3 Faculty of Electronic Engineering, Babol Noshirvani University of Technology, Shariati St, Babol, Iran 